\title{
Reinventing Cartography: Jhumpa Lahiri's Interpreter of Maladies and The Namesake
}

\author{
Daniela Cordeiro Soares Silva
}

\begin{abstract}
By taking Lahiri's map imagery as a starting point, I reflect on the author's portrayal of the Indian diaspora and the way she builds up a narrative that questions many of the ontological and solid beliefs established by hegemonic discourses, including the concepts of fixed identities and gender roles.
\end{abstract}

Key words: Diaspora. Postcolonialism. Maps. Identity. Gender.

Maps are known to play an important role in the history of colonization, domination and the making of the world, both visually and ideologically speaking. When we turn to the history of maps, we can see that they are more than simply the representation on paper of the earth's surface, and that in fact, they also act as textual inscriptions of power. They become, in a way, the scientific proof of what the geographer claims as territory. As José Rabasa explains, "[t]he written solidifies locations while supplying meaning to the visual" (Rabasa 361). Tiffin and Lawson (3) also study the relation of maps and power and they stress that if guns initiated imperial domination was initiated by guns, they were maintained by textuality and, in this case, maps act as textual references to establish domination. Therefore, to write or to draw a map means to have the power to supply, to fill the visual element with meanings. As part of the process of inscribing meanings onto a map, there is the attempt of hegemonic forces to create the illusion of distinct places occupied by homogeneous groups of people, an illusion that endorses the notions of existing fixed and unified cultures and identities.

In a mapped world, the concepts of culture and identity are often grounded on the relation of subjects and the space they come to occupy, or the location of subjects on the map. The frozen picture of borders on the surface of paper inspires a logical, natural, rigid and permanent organization of the world. These borders bring the idea that the world is precisely divided into homogeneous nations or groups of people sharing a common culture and identity and separated from other groups, for instance, as Kipling states "East is East, and West is West, and never the twain shall meet" (190).

The movements of the new diasporas in a postmodern world, which includes the movements of postcolonial subjects, come to disturb the organization of the maps imposed by hegemonic discourses and to bring inconsistency to the rigid notions of 
culture and identity. If I use the word "inconsistency," I do so not in negative terms, nor conveying the idea of disorder and confusion in opposition to the logic maintained by a map. On the contrary, inconsistency here carries the notion of movement that creates the condition for negotiation and re-invention of identities as it destabilizes the rigid relation of place and self. The notion of inconsistency that I use matches Wisker's use of the term "unsettling" to describe the movement of postcolonial subjects in the sense that, "[p]ost-colonial migrants both unsettle and enrich what was thought of as the centre of imperial powers" (16). As Wisker points out, inconsistency can also be felt in the relation between the migrant and the center of power, as she shows that migrants unsettle, but also enrich, power relations. Out of this ambivalent relationship, Wisker believes that it is the task of diasporic and migrant writers to "reflect on, record, imagine beyond, and articulate newly changed, merged, differently focused perspectives on their adoptive cultures, and their position as writers with multiple roots in the history of several cultures."

The fact that Jhumpa Lahiri is the child of Indian immigrants and that she also crosses borders when she migrates from England - where she was born - to become an American citizen makes her both a migrant and diasporic writer. ${ }^{1}$ In her work, she reflects on the Indian diaspora and creates a narrative that reveals the inconsistency of the concepts of identity and gender roles in the space of diaspora. Thus, it is my intention to discuss the attempt of hegemonic discourses to solidify notions of space, roles and identities on a map, and the way Lahiri transforms these notions into fluid spaces when she portrays diasporic experiences in her book of short stories, Interpreter of Maladies, and in her novel, The Namesake.

In my title I speak of cartography - and of its reinvention - for two different reasons. First, the term cartography is used to call attention to the map imagery in Lahiri's works. Second, to discuss the attempts of hegemonic discourses to "map," or to determine fixed roles and identities to different groups of people. The map imagery in both Lahiri's book of short stories and novel questions the very meaning of the act of mapping. For instance, many of Jhumpa Lahiri's characters turn to a map in an attempt to locate, experience and understand India. For them, understanding is closely connected to locating, or visualizing what they cannot experience, and a map seems to be a good starting point, especially because they are believed to offer a real and accurate representation of the world. As an example, in the episode when Lilia - a second-generation Indian and the main character of Lahiri's short story "When Mr. Pirzada came to Dine" - calls Mr. Pirzada an Indian, her father's reaction is to take her to a map so she can understand the "current situation" of India. What he means by the "current situation" are the conflicts between India and Pakistan after the Partition, but the simple division of the territories of India and Pakistan in a map is not enough to explain difference to Lilia, as she states:

It made no sense to me. Mr. Pirzada and my parents spoke the same language, laughed at the same jokes, looked more or less the same. [...] Nevertheless my father insisted that I understand the difference, and he led me to a map of the world taped on the wall over his desk. He seemed concerned that Mr. Pirzada might take offense if I accidentally referred to him as an Indian. (Interpreter 25)

When Lilia tries to understand the difference between her father and Mr. Pirzada, she shows that the organization of the world - or the division of people in homogeneous and distinct groups - is not solid and fixed like the structure of a map. On the other hand, this organization comes to be a fluid one that allows imaginable encounters, as Lilia testifies the encounter of a Muslim and a Hindu having dinner 
together. The reality of the maps imposes separation, but the reality that Lahiri's characters' experience in diaspora suggests togetherness.

As Lahiri's characters try to interpret what they see on the maps, we conclude that geographical delimitation does not define identity for them. Place and space in her stories, contrary to what cartography determines as measurable, organized and fixed sites, become immeasurable, infinite sites for discovery and negotiation, and because of this, frontiers are often transformed and dematerialized in her images. Roland Walter, in his analysis of Dione Brand's novel In Another Place, not Here, states that the main theme in Brand's novel is not the politics of a geographical location as the title may imply, but a politics of "multidimensional location," or location in and through the body, sex, gender, color and history (Walter 83). Transposing Walter's idea of a "multidimensional location" to Lahiri's stories and novel allows the creation of a new map, or other productive but also conflicting spaces between west/east, India/Europe, India/US, India/Pakistan, ex-colonizer/ex-colonized, Indian immigrant/secondgeneration Indian, Indian men/Indian women.

In these new spaces, Lahiri's characters learn to negotiate not only the differences between the Indian immigrants and American citizens, but also the conflicts brought up by the clash of different groups of Indian immigrants, or of Indian immigrants and their second-generation Indians. When Lahiri brings all these encounters to her works, she creates a dialogue between the subjects of the diaspora rather than privileging a dialogue of these subjects with their former colonizers. Consequently, these characters' perceptions of the problems to understand each other allow us to question the binary oppositions that separate east from west, as we learn that this division does not imply two homogeneous groups of people. Thus, and as we can see through the encounter of Lilia and Mr. Pirzada, negotiation and affiliation happen not only when east and west are put together, but also when east meets east. These encounters generate different borders and a movement of negotiation of identities that is brought by their crossing.

In this fluid reality Lahiri's characters will negotiate their positions in a map, a negotiation that includes not only their conflicts to understand their "Indianness" or "Americanization," but also conflicts with reference to gender roles. My concern regarding questions of gender when analyzing Lahiri's matches James Clifford's assumption that the issues of gender, especially the effect of the diaspora in gender relations, allows for a more critical gaze upon the analysis of diasporic movements (313-14). For him, there is a striking difference between the experiences of diasporic men and women as the diasporic experiences are always gendered.

In her works, Lahiri explores this difference between the experiences of diasporic men and women that Clifford refers to. For instance, the Indian men portrayed by Lahiri find the raison-d'être for their process of migration in the "search for the American dream," as they migrate for academic and economic purposes, in the search for better opportunities in life. Lahiri's immigrant women, for their part, have a completely different migration experience. They migrate either to accompany their husbands or to meet them for the first time, following the practice of arranged marriage. They are always "brought" to America, as Mrs. Sen, the main character of Lahiri's eponymous short story, puts it: "[h]ere, in this place Mr. Sen has brought me, I cannot sometimes sleep in so much silence" (Interpreter 115). Once in America, Lahiri's women have to accept life away from their families and other Indian women, who previously represented their extended family, having to put up with different cultural habits in terms of childcare, household chores and food. 
Although Lahiri explores the diverse experience of both men and women in diaspora in her short stories, it is in her novel that this issue is better developed. Very often we have the feeling that some of the immigrant experiences explored by Lahiri in her novel can be a development of one or more of her short stories, at the same time that it produces the opposite effect, that is, the short stories seem to complete her narrative in the novel. As an example, we can see that Lahiri suggests that the transaction of women in the practice of arranged marriages has preceded the migration of all Indian women in her short stories, but it is in her novel that she describes this event when she gives, on the first pages of The Namesake, a detailed account of Ashima's experience. An obedient daughter, and dedicated mother and wife, Ashima is about to give birth to her first child in a hospital in the United States, as the narrator brings back images of her past in India and of the day she first met her husband. He had been the third man to whom she had been offered. The description of his visit to Ashima's house illustrates the way marriage is arranged like a deal in which women become commodities:

Ashima had paused in the corridor. She could hear her mother saying, "She is fond of cooking, and she can knit extremely well. Within a week she finished this cardigan I am wearing." Ashima smiled, amused by her mother's salesmanship; it had taken her the better part of a year to finish the cardigan, and still her mother had to do the sleeves. (Namesake 7)

Also, it is in her novel that Lahiri explores the intertwining of the experience of being a woman and an immigrant as she describes Ashima going through the experience of pregnancy. When Ashima is in hospital waiting to give birth to her first child, she reflects on her situation as an immigrant. She suffers from the pain of parturition but she does not know if the most painful thing is the act of giving birth or the fact that she is an immigrant, a stranger in that land in which she does not know the people around her. Likewise, she fails to understand the subtleties of the English language. The narrator comments on the episode:

For being a foreigner, Ashima is beginning to realize, is a sort of lifelong pregnancy - a perpetual wait, a constant burden, a continuous feeling out of sorts. It is an ongoing responsibility, a parenthesis in what had once been ordinary life, only to discover that that previous life has vanished, replaced by something more complicated and demanding. Like pregnancy, being a foreigner, Ashima believes, is something that elicits the same curiosity from strangers, the same combination of pity and respect. (Namesake 49)

During the narrative Ashima realizes the vanishing of her previous life, especially the emptying of traditions like the practice of arranged marriage and exchange of women when it is time for her children to get married. Now, in the space of diaspora, the territory is new and the tradition of arranged marriages is emptied of meaning. In an attempt to keep this tradition, Ashima faces the failure of her son's marriage to a second-generation Indian and feels guilty for being the one who had encouraged their engagement. After this failure, she accepts the fact that her daughter Sonia has a modern relationship to a "half-Jewish, half-Chinese" man. The acceptance of Sonia's wedding is part of Ashima's process of transformation in the space of diaspora. Even if she went to the United States only to accompany her husband, it is there that she finds the means to re-draw the frontiers that limited her space as a woman. After her husband's death, Ashima starts working in a library, learns how to drive and offers Christmas parties to her neighbors. Although in the end of the novel she is preparing to go back to Calcutta, this movement does not represent going back to the space of limitation, as we can observe when the narrator stresses the different woman Ashima 
has become: "She has learned to do things on her own, and though she still wears saris, still puts her long hair in a bun, she is not the same Ashima who had once lived in Calcutta. She will return to India with an American passport" (Namesake 276). Slowly in the narrative, Ashima becomes what her name means in Bengali: "without borders, without a home of her own, a resident everywhere and nowhere" (Namesake 276).

I would like to stress that as I analyze the experiences of Lahiri's characters in the space of diaspora, I am careful not to take her descriptions as a representation of "the" Indian immigrant, or immigrant and second-generation women. In fact, when Lahiri portrays the deterritorialized Indian women for example, she does exactly the opposite as she foregrounds the need for negotiation and performance of roles and identities. The range of experiences and outcomes depicted by Lahiri makes of her a writer concerned with cultural, historical and political specificities resulting not in the homogenization of women as a group, but in the presentation of different and specific experiences that signal a range of alternative possibilities for women as diasporic subjects (Almeida 334). Thus, even if the experiences of Lahiri's characters coincide in terms of their insertion in an oppressive patriarchal system, the (Indian, immigrant Indian and second-generation Indian) women portrayed are not the same in Lahiri's stories. The dislocation and deterritorialization of bodies become necessary tropes to negotiate their condition, but they have different alternatives to come to terms with their situation in the new territory.

These new alternatives are what I name the cartography reinvented by Lahiri, a new cartography that comes not only from the dismantling of systems that impose the fixed spaces of national and gender identities, but also from the creation of new, fluid spaces, built through a continuous intersection and juxtaposition of different cultures, roles and identities. These new spaces represent the ideal sites for the negotiation and performing of hybrid identities, they become the spaces for a perpetual transit in which Lahiri's characters finally find "home," a fluid home that fluctuates in-between the "not anymore" and the "not yet" (Bhabha 36-37). As a space in the between, this new home becomes a border site through which Lahiri's characters can experience the proliferation of cultural transferences especially in their relation with memory, food and language. The fragmentation of memory, the juxtaposition of ingredients in cooking and the act of translation become ideal spaces to experience hybrid identities. The acts of re-membering, trying new tastes, becoming translated beings and re-interpreting identities represent the final picture of the cartography reinvented by Lahiri - through the creation of fluid maps, spaces and identities.

Lahiri's use of imagery of fluid maps and frontiers makes us think about and question the concept of fixed places and identities, the idea of homeland, the fixed spaces of east and west, of men and women. Where is home? What is Indian? What is American? What is being an Indian woman like? What about an immigrant Indian woman? Through Lahiri's work we learn that there is not a single and fixed answer for these questions. The way Lahiri's characters experience migration changes their perception of places, roles and identities. For instance, her characters' perception of home, or homeland, changes as we can see that India may represent the home Lahiri's immigrant characters want to go back to, but in the end, they see that home does not exist except as memory, but a memory which has also been transformed. For the second-generation Indians, home is the USA, or the place in which they were born, and sometimes they feel as foreigners within their own family. They often experience feelings of rejection in relation to the traditions their parents celebrate and sometimes 
consider some rituals as impositions. However, even if they try to escape the Indian traditions that surround them, they also go back to them when they need. In fact, for Lahiri's characters, home turns out to be this space of in-betweeness, or the space for negotiation.

If many of Lahiri's stories touch upon what could be stated as a negative side of the migration experience - such as the feelings of loss, loneliness and prejudice involving the immigrant's life - she does not limit migration stories to stories of suffering, horror and victimization. Her stories of displacement are also statements of belonging not to one particular culture, but to the two (or more) cultures in question. It is a matter of addition and negotiation, rather than loss and acceptance.

As Lahiri's characters show, dealing with the clash of two or more worlds means the possibility of a life in transit, or in-between. There is no home to go back to, no identity to claim, no maps to establish as true. The immigrant's situation always implies an interrogation, a constant questioning and negotiation. Negotiation is the point of arrival, "the third and final continent," as the title of one of Lahiri's stories suggests, but above all a reinvented and fluid one.

\footnotetext{
Notas

$\prod_{1}$

In spite of being aware of the problems raised by the use of the term "American" to refer to the United States of America - as the term wipes out the existence of other "Americas" - I have decided to use it because this is the term chosen by Lahiri to describe the people and traditions of that country.
}

Resumo

Ao tomar as imagens de mapas presentes nas obras de Lahiri como ponto de partida, proponho uma reflexão sobre como a autora descreve a diáspora indiana e constrói uma narrativa questionadora de crenças solidificadas e tornadas ontológicas por discursos hegemônicos, como os conceitos de identidades fixas e papéis de gênero.

Palavras-chave: Diáspora. Pós-colonialismo. Mapas. Identidade. Gênero.

\author{
Works Cited
}

Almeida, Sandra Regina Goulart. "Escrituras Migrantes: Sujeitos

Femininos em Deslocamentos." Refazendo Nós, Florianópolis:

Editora Mulheres, 2004. 329-36.

Bhabha, Homi K. The Location of Culture. London: Routledge, 1998.

Clifford, James. "Diaspora." Cultural Anthropology 9.3 (1994): $302-$

38.

Kipling, Rudyard. "The Ballad of East and West." The Complete Verse. London: Kyle Cathie, 1990. 190-93.

Lahiri, Jhumpa. Interpreter of Maladies. New York: Houghton Mifflin, 1999. 
Lahiri, Jhumpa. The Namesake. New York: Houghton Mifflin, 2003.

Rabasa, José. "Allegories of Atlas." The Post-Colonial Studies

Reader. Local? Routledge, 1997. 358-64.

Tiffin, Chris and Allan Lawson. Des-cribing Empire. London: Routledge, 1994.

Walter, Roland. "(Re)visões da Diáspora Negra: os Entre-lugares Migratórios e Identitários na Ficção de Dionne Brand." Gênero e Representação em Literaturas de Língua Inglesa. Gazzola , Ana Lúcia; javascript:outroAcervo(")Duarte, Constância Lima; Almeida, Sandra Regina Goulart (Org.). Belo Horizonte: Departamento de Letras Anglo-Germânicas, Faculdade de Letras/UFMG, 2002. 82-91.

Wisker, Gina. Post-Colonial and African American Women's Writing: A Critical Introduction. New York: St. Martin's, 2000. 